\title{
Characterization and Photocatalytic Activity of Enhanced Copper-Silica-Loaded Titania Prepared via Hydrothermal Method
}

\author{
Ramarao Poliah and Srimala Sreekantan \\ School of Materials and Mineral Resources Engineering, Universiti Sains Malaysia, Engineering Campus, Nibong Tebal, \\ Seberang Perai Selatan, 14300 Pulau Pinang, Malaysia \\ Correspondence should be addressed to Srimala Sreekantan, srimala@eng.usm.my
}

Received 11 March 2011; Revised 24 May 2011; Accepted 13 July 2011

Academic Editor: Edward Andrew Payzant

Copyright ( $) 2011$ R. Poliah and S. Sreekantan. This is an open access article distributed under the Creative Commons Attribution License, which permits unrestricted use, distribution, and reproduction in any medium, provided the original work is properly cited.

$\mathrm{TiO}_{2}$ nanopowder, loaded with $\mathrm{SiO}_{2}$ and $\mathrm{Cu}-\mathrm{SiO}_{2}$, was prepared under both acidic and basic environments via the hydrothermal method. The morphology and structure of $\mathrm{TiO}_{2}$ were studied by XRD, TEM, and FT-IR. The photocatalytic activity of samples was studied by monitoring the degradation of methyl orange, using a UV-visible spectrophotometer. The effect of Ti/Si ratio, $\mathrm{pH}$, and $\mathrm{Cu}^{2+}$ addition on the formation of $\mathrm{TiO}_{2}$ and its photocatalytic activity was investigated in detail. The results show that a large surface area and a high surface acidity were important factors to achieve good $\mathrm{TiO}_{2}$ performance. The presence of Ti-O-Si bonding enhanced surface acidity, which improved its ability to adsorb more hydroxyl radicals and increased its surface area. The addition of $0.1 \mathrm{~mol} \%$ concentration of $\mathrm{Cu}^{2+}$ and $25 \mathrm{~mol} \% \mathrm{SiO}_{2}$ in $\mathrm{TiO}_{2}$ induced the formation of new states close to the conduction band, which narrowed the band gap energy and enhanced the photodegradation efficiency.

\section{Introduction}

In recent years, cases of air and water pollution have been increasing due to the continuous rise in population and urbanization. Improper waste management has been identified as one of the prime factors that contribute to the pollution. In 2003, the average amount of municipal solid waste (MSW) generated in Malaysia was $0.5-0.8 \mathrm{~kg} /$ person/day, which has further increased to $1.7 \mathrm{~kg} /$ person/day in major cities [1]. Solid waste management continues to be a major challenge throughout the world, particularly in rapidly growing cities and towns [2].

Land filling and incineration are two of the most common methods of solid waste disposal. Unlike land filling, incineration requires minimum land, reduces the volume of solid waste by half, and can be operated in any weather. Nevertheless, emission of pollutants, especially dioxin and furan, is the major drawback of incineration. Among the various solutions available, photocatalysis is considered to be a green technique that has great potential to decompose contaminants without leaving harmful intermediates [3-5]. Choi et al. reported that the polychlorinated dibenzo-pdioxins such as mono-, tetra-, hepta-, and octachlorinated congeners were successfully degraded by a $\mathrm{TiO}_{2}$ film under UV or solar light irradiation [6].

Titanium dioxide is the most promising photocatalyst due to its superior properties such as low cost, environmental compatibility, and long-term photochemical stability [7-10]. However, its wide band gap energy (3.0 for rutile; 3.2 for anatase) limits its use as a photocatalyst in various applications. The large surface area, high crystallinity, low crystallite size, and crystal structure are important properties that influence the photocatalytic activity of $\mathrm{TiO}_{2}$. In recent years, much effort has been directed toward $\mathrm{TiO}_{2}$ modification to enhance its photocatalytic activity [11-15]. For instance, $\mathrm{TiO}_{2}$ loaded with various secondary oxides, such as $\mathrm{ZrO}_{2}$ [16], $\mathrm{WO}_{3}, \mathrm{MnO}_{2}, \mathrm{CuO}, \mathrm{V}_{2} \mathrm{O}_{5}$, and $\mathrm{Al}_{2} \mathrm{O}_{3}$ [17] and transition metals salt such as $\mathrm{Cu}^{2+}[18]$ and $\mathrm{Fe}^{2+}[19,20]$, has been reported to be a more efficient photocatalyst than pure $\mathrm{TiO}_{2}$. The composite $\mathrm{TiO}_{2}-\mathrm{SiO}_{2}$ has attracted great interest 
TABle 1: Photocatalytic activity of $\mathrm{TiO}_{2}$ with various $\mathrm{SiO}_{2}$ content.

\begin{tabular}{|c|c|c|c|c|}
\hline Ti/Si ratio $(\%)$ & Preparation method & Crytallite size (nm) & Phase structure & Photocatalytic activity (\%) \\
\hline $1: 1(50 \%)[18]$ & Sol-gel $\left(100^{\circ} \mathrm{C}, 1 \mathrm{~h}\right)$ & $5-8$ & A: $100 \%$ & $90(\mathrm{MB}, 2 \mathrm{~h})$ \\
\hline $1: 1(50 \%)[19]$ & Sol-gel $\left(100^{\circ} \mathrm{C}, 9 \mathrm{~h}\right)$ & $100-120$ & A: $100 \%$ & 95 (Rhodamine B, 2 h) \\
\hline $19: 1(5 \%)[20]$ & Sol-gel $\left(500^{\circ} \mathrm{C}, 1 \mathrm{~h}\right)$ & 6.7 & A: $100 \%$ & $73(\mathrm{MO}, 1 \mathrm{~h})$ \\
\hline $3: 1(25 \%)[21]$ & Sol-gel $\left(550^{\circ} \mathrm{C}, 2 \mathrm{~h}\right)$ & $4.5(\mathrm{~A}) 9.2(\mathrm{R})$ & A: $43.3 \%$ & $65(\mathrm{MO}, 2 \mathrm{~h})$ \\
\hline $7: 3(30 \%)[22]$ & Sol-gel $\left(800^{\circ} \mathrm{C}, 2 \mathrm{~h}\right)$ & 12 & A: $100 \%$ & $92(\mathrm{MO}, 5 \mathrm{~h})$ \\
\hline $3: 2(40 \%)[23]$ & Hydrothermal $\left(140^{\circ} \mathrm{C}, 10 \mathrm{~h}\right)$ & 7 & A: $100 \%$ & $95(\mathrm{MB}, 1 \mathrm{~h})$ \\
\hline $3: 1(25 \%)[24]$ & Hydrothermal $\left(200^{\circ} \mathrm{C}, 24 \mathrm{~h}\right)$ & 16.3 & A: $100 \%$ & $80(\mathrm{MB}, 8 \mathrm{~h})$ \\
\hline
\end{tabular}

A: anatase, R: rutile, MB: methyl blue, MO: methyl orange.

because of its ability to prevent the grain growth of $\mathrm{TiO}_{2}$ particles and enhance the thermal stability for the phase transformation of $\mathrm{TiO}_{2}$ from anatase to rutile [21-27]. Xu et al. [24] studied the effect of a wide range of $\mathrm{SiO}_{2}$ levels added to the microstructure and the photocatalytic activity of $\mathrm{TiO}_{2}$ powder; preparation involved the sol-gel method and calcination at various temperatures. Addition of $\mathrm{SiO}_{2}$ resulted in a marked reduction in grain size and an increase in the surface area of the catalyst. Results of other studies are summarized in Table 1. Although many reports describe the effect of $\mathrm{SiO}_{2}$ on the photocatalytic activity of $\mathrm{TiO}_{2}$, the results do not agree with one another, possibly due to differences in the processing methods or experimental conditions. On the other hand, Chen et al. [18] has been reported that 0.1 wt $\%$ of $\mathrm{Cu}^{2+}$-doped $\mathrm{TiO}_{2}-\mathrm{SiO}_{2}$ showed higher photocatalytic activity than that of undoped $\mathrm{TiO}_{2}-\mathrm{SiO}_{2}$. The effects of $\mathrm{pH}$ value on pure $\mathrm{TiO}_{2}$ formation have been reported by several groups $[28,29]$. Yu et al. prepared $\mathrm{TiO}_{2}$ powder at different $\mathrm{pH}$ values through the hydrothermal method [28]. They found that the $\mathrm{pH}$ value of the starting solution has a significant effect on the crystallinity, crystallite size, phase structure, and photocatalytic activity of the synthesized $\mathrm{TiO}_{2}$ powder. They proposed that basic conditions are favorable for the formation of pure anatase. Samples prepared at $\mathrm{pH} 9$ display higher photocatalytic activity. However, this result contradicts those obtained by Karami [29], who concluded that $\mathrm{TiO}_{2}$ prepared under acidic conditions ( $\mathrm{pH} 3)$ through the sol-gel method has higher photocatalytic activity.

Although the sol-gel method is widely used due to its simplicity and low cost, calcination in air is required for the formation of the anatase phase from amorphous $\mathrm{TiO}_{2}$. $\mathrm{Li}$ et al. [26] did a comparative study of the sol-gel and hydrothermal methods for the synthesis of $\mathrm{TiO}_{2}-\mathrm{SiO}_{2}$ composite nanoparticles and found that samples prepared through the hydrothermal route still possess a stable anatase phase, a large specific surface area, a small particle size, and a high photocatalytic activity even when calcined at $1000^{\circ} \mathrm{C}$. However, they did not report the effect of $\mathrm{pH}$ on the formation of $\mathrm{TiO}_{2}-\mathrm{SiO}_{2}$ nanoparticles. In the present study, the effect of $\mathrm{pH}$ values on photocatalytic activity and the optimum Ti/Si ratio for photocatalytic activity of $\mathrm{TiO}_{2}$ powder prepared by hydrothermal method were examined. The effect of $\mathrm{Cu}-\mathrm{SiO}_{2}$ addition on the phase structure and the photocatalytic activity of $\mathrm{TiO}_{2}$ were also studied.
TABLE 2: Crystal properties of $\mathrm{TiO}_{2}-\mathrm{SiO}_{2}$ oxide powder.

\begin{tabular}{lcccc}
\hline Sample & $\begin{array}{c}\text { Ti/Si } \\
\text { ratio }\end{array}$ & $\begin{array}{c}\mathrm{SiO}_{2} \\
\text { content } \\
(\%)\end{array}$ & $\begin{array}{c}\text { Final } \\
\mathrm{pH} \\
\text { value }\end{array}$ & $\begin{array}{c}\text { Crystallite size/nm } \\
(\text { XRD })\end{array}$ \\
\hline SA0 & $1: 0$ & 0 & 3 & 6.30 \\
SA 5 & $19: 1$ & 5 & 3 & 6.63 \\
SA10 & $9: 1$ & 10 & 3 & 7.06 \\
SA16 & $5: 1$ & 16.67 & 3 & 8.91 \\
SA20 & $4: 1$ & 20 & 3 & 9.54 \\
SA25 & $3: 1$ & 25 & 3 & 6.88 \\
SA25-Cu(0.05) & $3: 1$ & 25 & 3 & 10.8 \\
SA25-Cu(0.1) & $3: 1$ & 25 & 3 & 9.48 \\
SA25-Cu(0.15) & $3: 1$ & 25 & 3 & 9.62 \\
SA25-Cu(0.2) & $3: 1$ & 25 & 3 & 10.11 \\
SA25-Cu(0.5) & $3: 1$ & 25 & 3 & 8.21 \\
SA25-5 & $3: 1$ & 25 & 5 & 8.63 \\
SN25-7 & $3: 1$ & 25 & 7 & 9.98 \\
SA30 & $7: 3$ & 30 & 3 & 11.78 \\
SA50 & $1: 1$ & 50 & 3 & 11.76 \\
SB0 & $1: 0$ & 0 & 9 & 3.75 \\
SB16 & $5: 1$ & 16.67 & 9 & - \\
SB20 & $4: 1$ & 20 & 9 & - \\
SB25 & $3: 1$ & 25 & 9 & - \\
SB25-12 & $3: 1$ & 25 & 12 & - \\
SB25-14 & $3: 1$ & 25 & 14 & -57 \\
SB30 & $7: 3$ & 30 & 9 & - \\
SB50 & $1: 1$ & 50 & 9 & - \\
\hline SA: & & - \\
\hline
\end{tabular}

SA: acid, SB: basic, SN: neutral.

\section{Experimental Procedure}

2.1. Preparation. Initially, the oxide powder $\mathrm{TiO}_{2}-\mathrm{SiO}_{2}$ with various $\mathrm{Ti} / \mathrm{Si}$ ratios at $\mathrm{pH} 3$ and 9 were prepared, and the photocatalytic performance was evaluated to select the optimum Ti/Si ratio. The Ti/Si ratios and $\mathrm{pH}$ values in the experiment are summarized in Table 2. Tetrabutylorthotitanate (TBOT) with a normal purity of 97\% (Aldrich, US) and tetraethylorthosilicate (TEOS) with a normal purity of $98 \%$ (Merck, Germany) were used as the source of titanium and silicon, respectively. Both were dissolved in equal volumes of ethanol, after which a few drops of hydrochloric acid were 


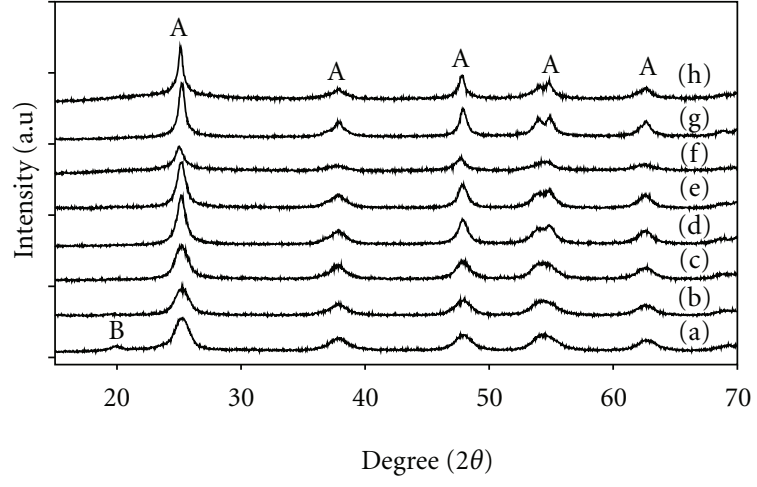

FIGURE 1: XRD patterns of the $\mathrm{TiO}_{2}$ powder prepared with different amounts of $\mathrm{SiO}_{2}$ at $\mathrm{pH} 3$ : (a) $0 \mathrm{~mol} \%$, (b) $5 \mathrm{~mol} \%$, (c) $10 \mathrm{~mol} \%$, (d) $16 \mathrm{~mol} \%$, (e) $20 \mathrm{~mol} \%$, (f) $25 \mathrm{~mol} \%$, (g) $30 \mathrm{~mol} \%$, and (h) $50 \mathrm{~mol} \%$. (A: anatase, B: brookite).

added to TEOS as catalyst. Afterward, the mixture was kept in a water bath maintained at $70^{\circ} \mathrm{C}$ for $2 \mathrm{~h}$. The TEOS and TBOT precursors were then mixed and stirred for 15 minutes before adding the desired amount of copper(II) nitrate. The $\mathrm{pH}$ values were adjusted by adding hydrochloric acid for the acidic condition and sodium hydroxide for the basic condition. This solution was stirred for $1 \mathrm{~h}$ at room temperature and placed in a Teflon-lined stainless steel autoclave, in which it was heated at $150^{\circ} \mathrm{C}$ for $24 \mathrm{~h}$, and then cooled to room temperature. The sample obtained was washed and then dried at $100^{\circ} \mathrm{C}$. A powder was obtained.

2.2. Characterization and Photocatalytic Degradation. The powder samples were characterized by X-ray diffraction (XRD) using a Bruker D8 powder diffractometer employing $\mathrm{Cu} \mathrm{K} \alpha$ radiation. The accelerating voltage and the applied current were $40 \mathrm{kV}$ and $40 \mathrm{~mA}$, respectively. The average crystallite size of the $\mathrm{TiO}_{2}-\mathrm{SiO}_{2}$ oxide powder was calculated using X-ray line broadening methods based on the Scherrer formula. Additionally, the morphology of the powder was observed by transmission electron microscopy (TEM) using a Philips $420 \mathrm{~T}$. The chemical structure information of the particles was obtained by Fourier transform infrared spectroscopy (Spectrum One, Perkin Elmer, US). Photocatalytic degradation studies were performed using $30 \mathrm{mg} / \mathrm{L}$ methyl orange (MO) solution. A total of $0.1 \mathrm{~g} \mathrm{TiO}_{2}-\mathrm{SiO}_{2}$ oxide powder was added to $30 \mathrm{~mL}$ of $\mathrm{MO}$ solution and photoirradiated for $1 \mathrm{~h}$ at room temperature using a TUV $18 \mathrm{~W}$ UV-C Germicidal light. The concentration of the degraded $\mathrm{MO}$ was determined using a UV-visible spectrophotometer (Varian, Cary 50 Conc).

\section{Results and Discussion}

3.1. Effect of $\mathrm{SiO}_{2}$ Content. XRD was used to analyze the formation of the crystalline phase of the $\mathrm{TiO}_{2}$ powder prepared with various amounts of $\mathrm{SiO}_{2}$ in both acidic and basic environments. Figure 1 illustrates the XRD patterns of $\mathrm{TiO}_{2}$ prepared at $\mathrm{pH} 3$ with various $\mathrm{Ti} / \mathrm{Si}$ ratios. The $\mathrm{TiO}_{2}$ prepared at various $\mathrm{Ti} / \mathrm{Si}$ ratios led to formation of the anatase phase. Patterns of samples without $\mathrm{SiO}_{2}(\mathrm{SA} 0)$ shows peak for

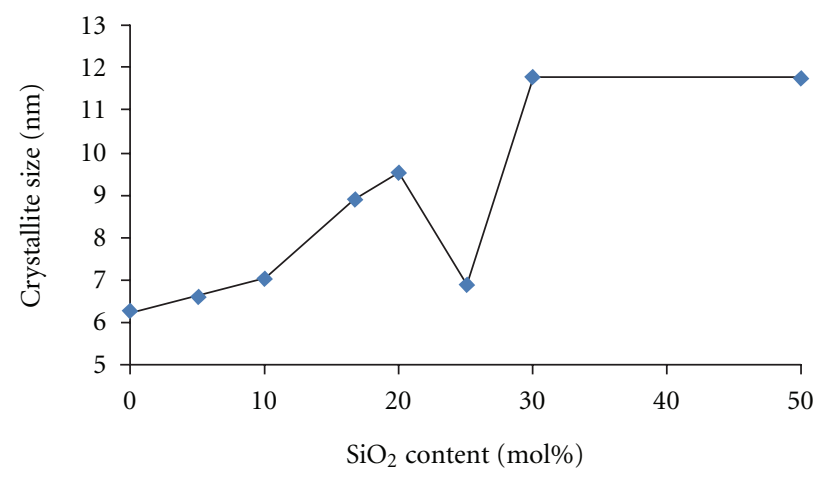

FIGURE 2: Relationship between the crystallite size and amount of $\mathrm{SiO}_{2}$ on $\mathrm{TiO}_{2}$ powder prepared at $\mathrm{pH} 3$.

anatase and a small peak for the brookite phase at a diffraction angle of $\sim 20^{\circ}$. The relative intensities of the anatase diffraction peaks in each sample are different; this suggests that the degree of crystallinity is affected by the $\mathrm{SiO}_{2}$ content. A high crystallinity of $\mathrm{TiO}_{2}$ was obtained with addition of $30 \mathrm{~mol} \% \mathrm{SiO}_{2}$ (SA30), whereas low crystallinity was observed in samples with $25 \mathrm{~mol} \% \mathrm{SiO}_{2}$ (SA25). $\mathrm{No} \mathrm{SiO}_{2}$ crystal phase was identified in all samples. This indicates that $\mathrm{SiO}_{2}$ existed as an amorphous phase in the $\mathrm{TiO}_{2}-\mathrm{SiO}_{2}$ composite.

The formation of brookite phase in sample SA0 (acidic condition) could be explained as follows [28]: $\mathrm{Ti}(\mathrm{OH})_{x}\left(\mathrm{OC}_{4} \mathrm{H}_{9}\right)_{4-x}$ forms as a result of hydrolysis reaction between TBOT and $\mathrm{HCl}$, where $x$ was related to the $\mathrm{pH}$ value of starting solution. Since the ligand field strength of $\mathrm{Cl}^{-}$ ions was larger than that of butoxy group in $\mathrm{HCl}$ solution, thus the $\mathrm{Cl}^{-}$ions could substitute the butoxy group in the $\operatorname{Ti}(\mathrm{OH})_{x}\left(\mathrm{OC}_{4} \mathrm{H}_{9}\right)_{4-x}$ complex and led to the formation of complex $\mathrm{Ti}(\mathrm{OH})_{2} \mathrm{Cl}_{2}$. The complex $\mathrm{Ti}(\mathrm{OH})_{2} \mathrm{Cl}_{2}$ actually existed in the form of $\mathrm{Ti}(\mathrm{OH})_{2} \mathrm{Cl}_{2}\left(\mathrm{H}_{2} \mathrm{O}\right)_{2}$ in a solution due to the $\operatorname{Ti}(\mathrm{IV})\left(3 \mathrm{~d}^{0}\right)$ complex ions are all octahedrally coordinated in solution and crystal. It is reported that $\mathrm{Ti}(\mathrm{OH})_{2} \mathrm{Cl}_{2}\left(\mathrm{H}_{2} \mathrm{O}\right)_{2}$ could be the precursor of brookite. This mechanism was favored to explain the occurrence of brookite in the sample.

The XRD patterns of $\mathrm{TiO}_{2}$ prepared at $\mathrm{pH} 9$ with various $\mathrm{Ti} / \mathrm{Si}$ ratios (not shown here) shows samples prepared without $\mathrm{SiO}_{2}(\mathrm{SB} 0)$ produced peaks characteristic of anatase at $2 \theta$ of $24,34,39$, and $48^{\circ}$, and the peak of rutile at $28^{\circ}$. However, the peak intensity of this sample is very low compared to those produced by samples prepared under acidic conditions; this indicates that the phase transformation to anatase or rutile was not fully achieved at basic conditions. In contrast, samples prepared with $\mathrm{SiO}_{2}$ generally showed amorphous $\mathrm{TiO}_{2}$. In basic conditions, $\mathrm{Na}^{+}$attacks the Ti-O-Ti bond, which results in the formation of a two-dimensional layered structure with dangling bonds that contribute to the formation of the amorphous phase. This is in good agreement with the TEM analysis which is discussed later.

The crystallite size of the $\mathrm{TiO}_{2}-\mathrm{SiO}_{2}$ powders prepared in acidic condition was calculated using Scherrer formula and plotted against $\mathrm{SiO}_{2}$ content. Figure 2 shows a nonlinear relationship between the crystallite size and the amount of added $\mathrm{SiO}_{2}$. The trend is contrary to results in the literature wherein 


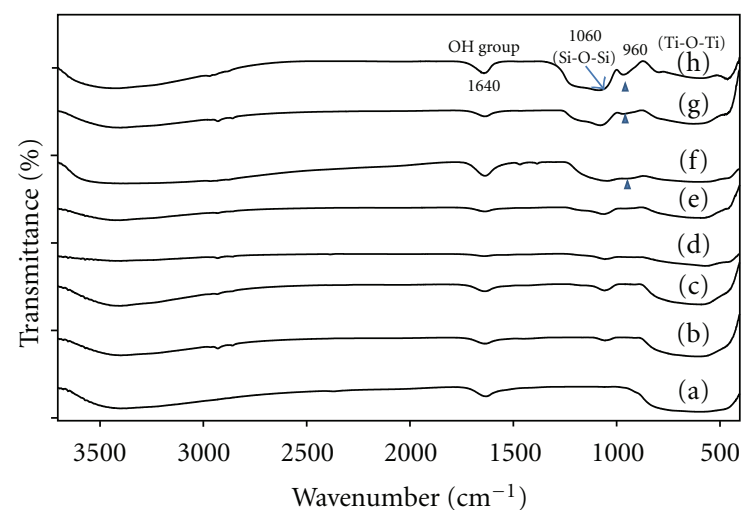

FIGURE 3: FTIR spectra of $\mathrm{TiO}_{2}-\mathrm{SiO}_{2}$ oxide powder containing $\mathrm{SiO}_{2}$ : (a) $0 \mathrm{~mol} \%$,(b) $5 \mathrm{~mol} \%$, (c) $10 \mathrm{~mol} \%$, (d) $16 \mathrm{~mol} \%$, (e) $20 \mathrm{~mol} \%$, (f) $25 \mathrm{~mol} \%$, (g) $30 \mathrm{~mol} \%$, and (h) $50 \mathrm{~mol} \%$. $\boldsymbol{\Delta}$ indicates absorption bands at $960 \mathrm{~cm}^{-1}$, which is characteristic of Ti-O-Si bonding.

$\mathrm{SiO}_{2}$ addition was found to retard grain growth of $\mathrm{TiO}_{2}$ and, therefore, reduce its crystallite size $[23,24,26]$. In the present study, the lowest crystallite size was $6.3 \mathrm{~nm}$ for pure $\mathrm{TiO}_{2}(\mathrm{SA} 0)$, and increased gradually with further addition of $\mathrm{SiO}_{2}$. However, the crystallite size of $\mathrm{TiO}_{2}$ for sample SA25 decreased drastically as the $\mathrm{SiO}_{2}$ amount reached $25 \mathrm{~mol} \%$; this may be attributed to the large surface area of the sample. Binary metal oxides are known to induce surface acidity [30]. The FTIR spectra of the $\mathrm{TiO}_{2}-\mathrm{SiO}_{2}$ powder at various $\mathrm{SiO}_{2}$ contents are shown in Figure 3. When the $\mathrm{SiO}_{2}$ content reached $25 \mathrm{~mol} \%$, a small peak at $960 \mathrm{~cm}^{-1}$ corresponding to the Ti-O-Si bond was observed. The presence of this oxide might have increased the surface acidity of the sample. Higher surface acidity led to a higher degree of adsorption of the $\mathrm{OH}$ radicals $\left(1640 \mathrm{~cm}^{-1}\right)$ and resulted in a larger surface area. The surface area was inversely proportional to grain size. The Ti-O-Si band intensity increased with addition of $30-50 \mathrm{~mol} \% \mathrm{SiO}_{2}$, and the intensity of bands for the hydroxyl group decreased. These indicate that large amounts of $\mathrm{SiO}_{2}$ (30-50 mol\%) in $\mathrm{TiO}_{2}$ cannot effectively improve the surface acidity and prevent the growth of $\mathrm{TiO}_{2}$ grains. Therefore, in sample $\mathrm{SA} 25, \mathrm{SiO}_{2}$ effectively enhanced the surface acidity, suppressed the grain growth of $\mathrm{TiO}_{2}$, and produced smaller crystallite size. The peak for the asymmetric stretching of Si$\mathrm{O}-\mathrm{Si}$ at $1060 \mathrm{~cm}^{-1}$ clearly increased with addition of $\mathrm{SiO}_{2}$, whereas the band intensity at $400-700 \mathrm{~cm}^{-1}$ (vibration of Ti-O bonds in Ti-O-Ti bonding) decreased. Therefore, the intensity of the peak for the Si-O-Si bond was inversely proportional to the intensity of the peak for the Ti-O-Ti bond.

3.2. Effect of $p H$ Value. Figure 4 shows the XRD pattern of $\mathrm{TiO}_{2}$ powder with $25 \mathrm{~mol} \% \mathrm{SiO}_{2}\left(\mathrm{TiO}_{2}-25 \mathrm{~mol} \% \mathrm{SiO}_{2}\right)$ at various levels of $\mathrm{pH}$. In the presence of $\mathrm{SiO}_{2}$, an acidic condition was favorable to form anatase structure. As the system is shifted from acidic to neutral, the intensity of the anatase peak $\left(2 \theta=25^{\circ}\right)$ and the crystallite size increased. Thus, $\mathrm{pH}$ value also affected the degree of crystallinity despite the presence of $\mathrm{SiO}_{2}$. At pH 12, the crystal structure of sample SB25-12 could not correspond to anatase, rutile, or brookite.

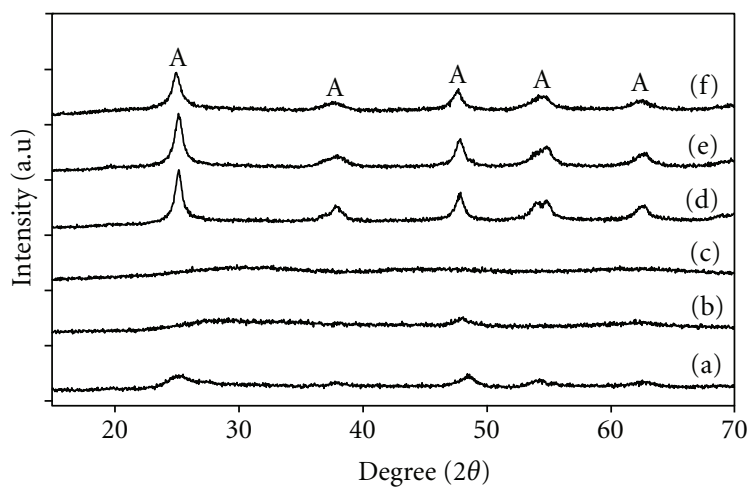

Figure 4: XRD pattern of $25 \mathrm{~mol} \% \mathrm{SiO}_{2}$-loaded $\mathrm{TiO}_{2}$ powder at various $\mathrm{pH}$ values: (a) $\mathrm{pH} 14$, (b) $\mathrm{pH} \mathrm{12,} \mathrm{(c)} \mathrm{pH} \mathrm{9,} \mathrm{(d)} \mathrm{pH} 7$, (e) $\mathrm{pH}$ 5, and (f) $\mathrm{pH}$ 3. (A: anatase).

It was similar to that of $\mathrm{Na}_{2} \mathrm{O}_{7} \mathrm{Ti}_{3}$ [31], $\mathrm{H}_{20} \mathrm{O}_{24} \mathrm{Si}_{3} \mathrm{Ti}_{4}$, and $\mathrm{H}_{4} \mathrm{Na}_{4} \mathrm{O}_{16} \mathrm{Si}_{4} \mathrm{Ti}_{2}$ probably due to their same layered titanate family [32]. Further increase in basic condition ( $\mathrm{pH} 14$ ) resulted in formation of the partial anatase phase, as seen in the TEM images of $\mathrm{TiO}_{2}-25 \mathrm{~mol} \% \mathrm{SiO}_{2}$ powders prepared at various $\mathrm{pH}$ values in Figure 5. Spherical like particles (Figures 5(a) and 5(b)) were observed in samples prepared in acidic and neutral conditions. At pH 12, a lamellar structure (two-dimensional layered structures) formed as a result of the reaction between the sample and $\mathrm{NaOH}$ (Figure 5(c)), which involved attack of $\mathrm{Na}^{+}$on the Ti-O-Ti bond. The edges of the lamellar structure might have many atoms with dangling bonds with enough energy to destabilize the twodimensional structures [33]. As the system shifted toward high $\mathrm{pH}$, the lamellar $\mathrm{TiO}_{2}$ deformed to saturate the dangling bonds. At pH 14, the transition three $\rightarrow$ two $\rightarrow$ one dimension was almost complete, while the lamellar structure formed tubes (Figure 5(d)); this resulted in a partial anatase phase. Thus, the $\mathrm{pH}$ appeared to have a significant effect on $\mathrm{TiO}_{2}$ phase structure and morphology.

Figure 6 illustrates the FTIR transmission spectra of $\mathrm{TiO}_{2}-25 \mathrm{~mol} \% \mathrm{SiO}_{2}$ powder prepared at various $\mathrm{pH}$ values and autoclaved at $150^{\circ} \mathrm{C}$ for $24 \mathrm{~h}$. The spectrum of pure $\mathrm{TiO}_{2}$ is also included as reference. The broad peaks at $3400 \mathrm{~cm}^{-1}$ and the peaks at $1640 \mathrm{~cm}^{-1}$ in all spectra are attributed to surface-adsorbed water and the bending mode of hydroxyl groups. The surface-adsorbed water and hydroxyl group decreased slightly as the $\mathrm{pH}$ increased; this is possibly due to the reduction in surface area of the sample, which prevented further water vapor absorption. This is consistent with the results wherein samples prepared at $\mathrm{pH} 3$ had higher photocatalytic activity compared with those prepared at $\mathrm{pH} 7$. The peaks, which were absent in pure $\mathrm{TiO}_{2}$, appeared at $960 \mathrm{~cm}^{-1}$ and $1040-1070 \mathrm{~cm}^{-1}$ due to the Ti-O-Si stretching and the asymmetric stretching vibration of $\mathrm{Si}-\mathrm{O}-\mathrm{Si}$, respectively. These peaks gradually decreased and eventually disappeared at higher $\mathrm{pH}$. This implies that the Ti-O-Si bonds weakened as the $\mathrm{pH}$ increased. The stretching vibration of Ti-O bonds in Ti-O-Ti can be observed at $400-700 \mathrm{~cm}^{-1}$. Peaks related to carboxyl groups were observed at the $1340-1470 \mathrm{~cm}^{-1}$ range. The carboxyl groups might be a result of oxidation 


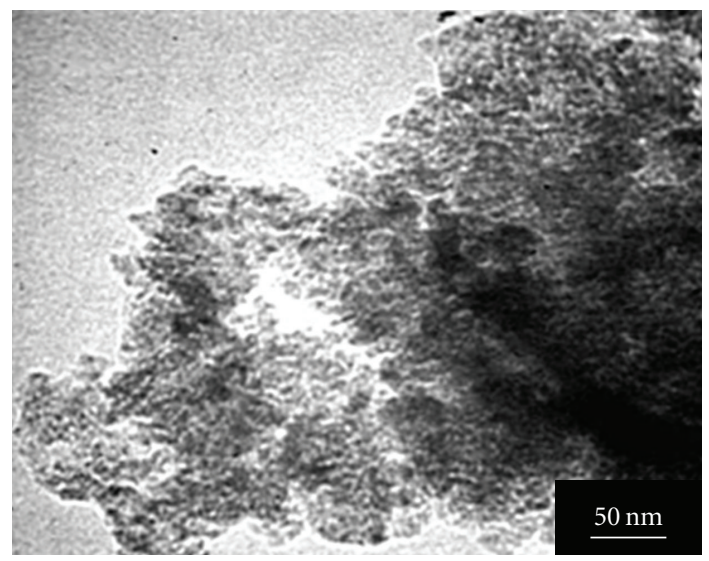

(a)

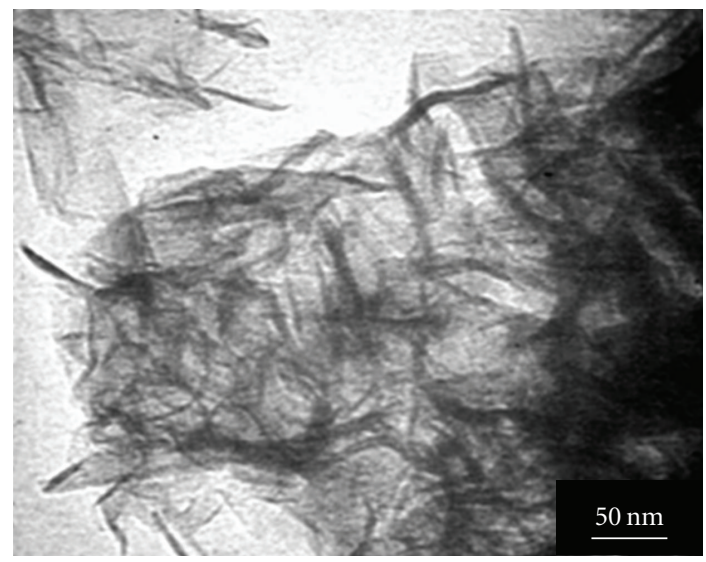

(c)

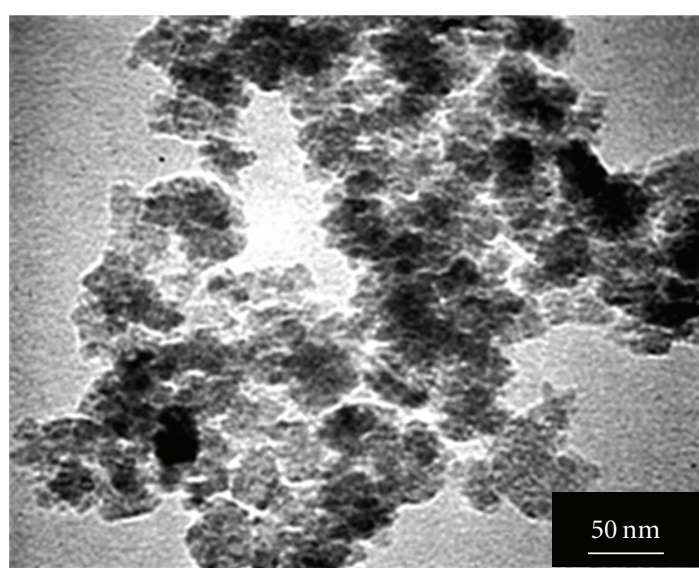

(b)

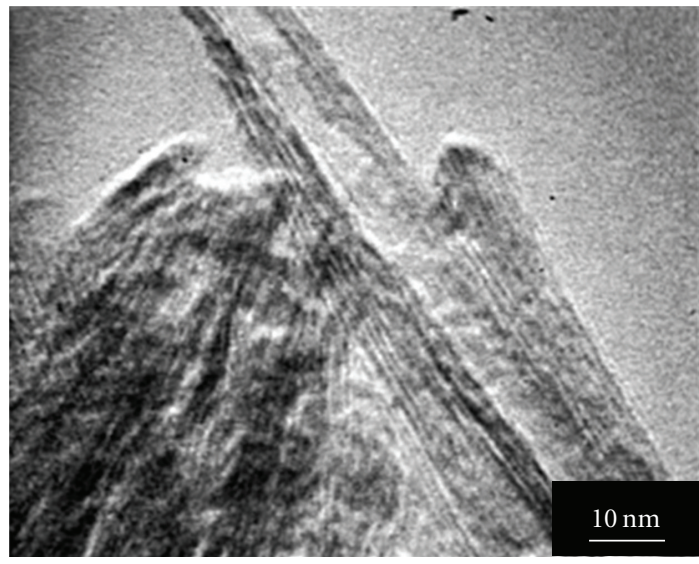

(d)

Figure 5: TEM images of $\mathrm{TiO}_{2}-25 \% \mathrm{SiO}_{2}$ oxide powder prepared at various $\mathrm{pH}$ values: (a) pH 3, (b) pH 7, (c) pH 12 , and (d) pH 14 .

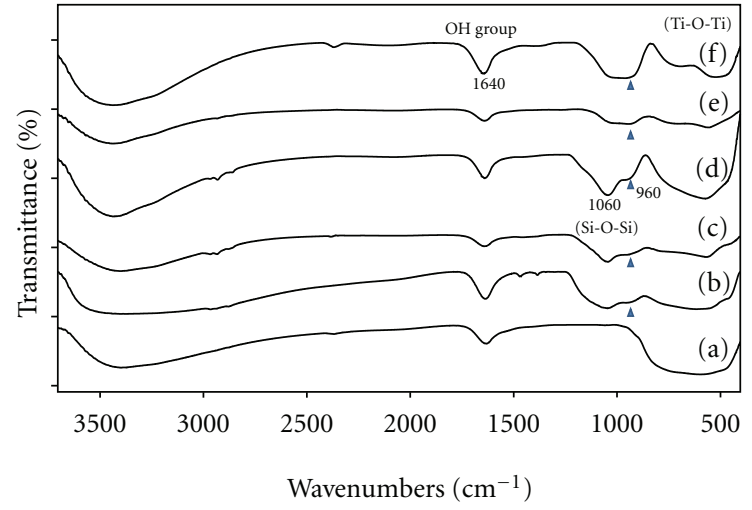

Figure 6: FTIR spectra of $\mathrm{TiO}_{2}-25 \% \mathrm{SiO}_{2}$ oxide powder prepared at various $\mathrm{pH}$ values: (a) pure $\mathrm{TiO}_{2}(\mathrm{pH} 3)$, (b) $\mathrm{pH} 3$, (c) $\mathrm{pH} 5$, (d) $\mathrm{pH} 7$, (e) $\mathrm{pH} 9$, and (f) $\mathrm{pH} 12 . \boldsymbol{\Delta}$ indicates absorption bands at 960 $\mathrm{cm}^{-1}$, which is characteristic of Ti-O-Si bonding.

of organic species during hydrothermal treatment [28]. As the preparation conditions shifted from acidic to basic, the oxidation process was inhibited; this caused the peaks to disappear completely.

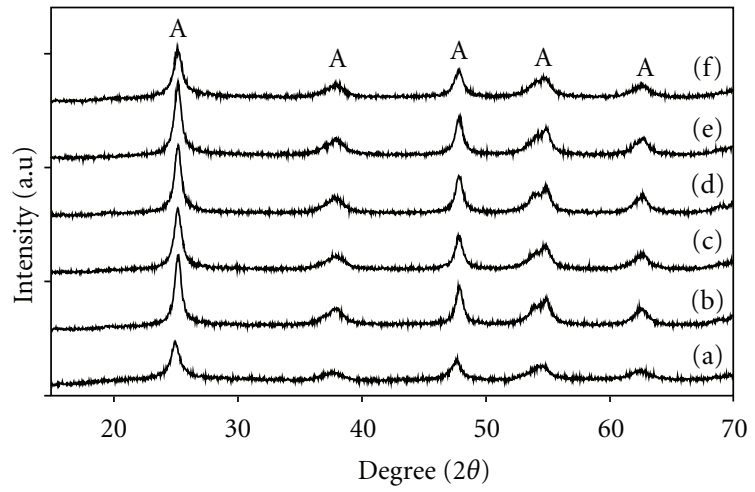

FIgURE 7: XRD pattern of $25 \% \mathrm{SiO}_{2}$-loaded $\mathrm{TiO}_{2}$ powder with various copper contents: (a) $0 \mathrm{~mol} \%$, (b) $0.05 \mathrm{~mol} \%$, (c) $0.1 \mathrm{~mol} \%$, (d) $0.15 \mathrm{~mol} \%$, (e) $0.2 \mathrm{~mol} \%$, and (f) $0.5 \mathrm{~mol} \%$. (A: anatase).

3.3. Effect of $\mathrm{Cu}^{2+}$ Addition in $\mathrm{TiO}_{2}-\mathrm{SiO}_{2}$ Powder. The XRD patterns of $\mathrm{Cu}^{2+}$-loaded $\mathrm{TiO}_{2}-\mathrm{SiO}_{2}$ are shown in Figure 7. The $\mathrm{TiO}_{2}-\mathrm{SiO}_{2}$ loaded with various amounts of $\mathrm{Cu}^{2+}$, maintained an anatase phase. The presence of $\mathrm{Cu}^{2+}$ was hardly detected by XRD due to its low content. However, the relative intensities of the anatase peak vary among samples. 


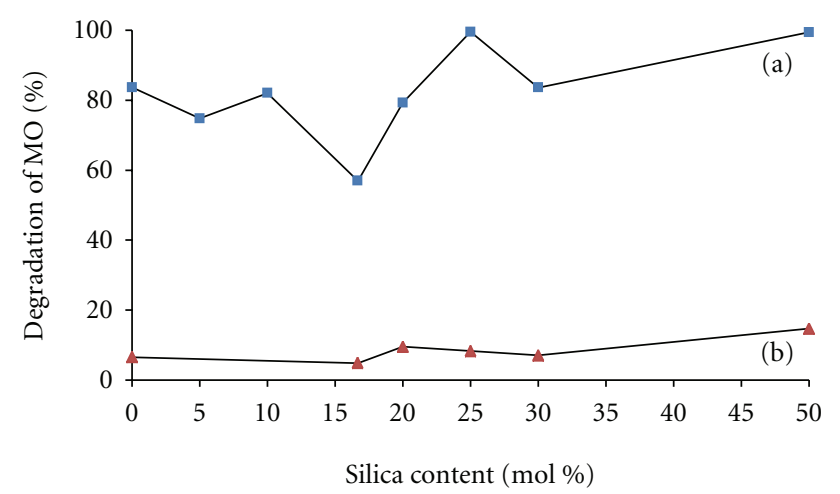

Figure 8: Photodegradation of $\mathrm{MO}(1 \mathrm{hr})$ on $\mathrm{TiO}_{2}-\mathrm{SiO}_{2}$ powder prepared at (a) $\mathrm{pH} 3$ and (b) $\mathrm{pH} 9$.

High $\mathrm{TiO}_{2}$ crystallinity was obtained with the addition of $0.2 \mathrm{~mol} \% \mathrm{Cu}^{2+}$ and lower degrees of crystallinity were observed in samples containing $0.5 \mathrm{~mol} \%$ copper, which were due to the poor distribution of $\mathrm{Cu}^{2+}$ in the $\mathrm{TiO}_{2}$ matrix. The $\mathrm{TiO}_{2}$ without $\mathrm{Cu}^{2+}$ produced relatively small diffraction peaks of anatase at $25^{\circ}$ (101), in contrast to the patterns of the samples with $\mathrm{Cu}^{2+}$. Therefore, phase transformation was not fully achieved without $\mathrm{Cu}^{2+}$, as the $\mathrm{TiO}_{2}$ retained portions of the inactive amorphous phase.

3.4. Photocatalytic Activity. The photocatalytic activity of the $\mathrm{TiO}_{2}-\mathrm{SiO}_{2}$ powder, prepared under acidic and basic conditions was evaluated through the degradation of methyl orange $(\mathrm{MO})$ under ultraviolet light irradiation for $1 \mathrm{~h}$ at room temperature. Evaluation was repeated for 3 times, and average values were plotted. Samples prepared in acidic conditions displayed photocatalytic activity higher than that of samples prepared in basic conditions (Figure 8). This is attributed to the presence of anatase in the samples prepared under acidic conditions. Photocatalytic activities of the samples with different Ti/Si ratio vary. Pure $\mathrm{TiO}_{2}(\mathrm{SA} 0)$ prepared in acidic conditions resulted in high photocatalytic activity. However, addition of 25 and $50 \mathrm{~mol} \%$ of $\mathrm{SiO}_{2}$ in $\mathrm{TiO}_{2}$ produced the highest photocatalytic activity compared with pure $\mathrm{TiO}_{2}$. Thus, the presence of $\mathrm{SiO}_{2}$ was essential to higher photocatalytic activity. As the $\mathrm{SiO}_{2}$ present in $\mathrm{TiO}_{2}$ promoted a high degree of anatase crystallinity, a lower crystallite size was produced due to suppression of $\mathrm{TiO}_{2}$ grain growth. This might have contributed to the larger surface area of the $\mathrm{TiO}_{2}$ particles. The addition of $\mathrm{SiO}_{2}$ in $\mathrm{TiO}_{2}$ also enhanced the acidity of the binary oxide. A model has been proposed to explain this increase in acidity [34]. In this model, the silicon cation enters the lattice of the host oxide, $\mathrm{TiO}_{2}$, and retains its original coordination number. Since the silicon cation is still bonded to the same number of oxygen atoms despite coordination changes in the oxygen atoms, a charge imbalance is created. The charge imbalance must be satisfied. Thus, Lewis sites are expected to form due to the positive charge in the $\mathrm{TiO}_{2}-\mathrm{SiO}_{2}$. The surface with improved acidity can adsorb more $\mathrm{OH}$ radicals, thus resulted in a larger surface area. This might enhanced the photocatalytic activity and led to complete degradation of MO. This is consistent with

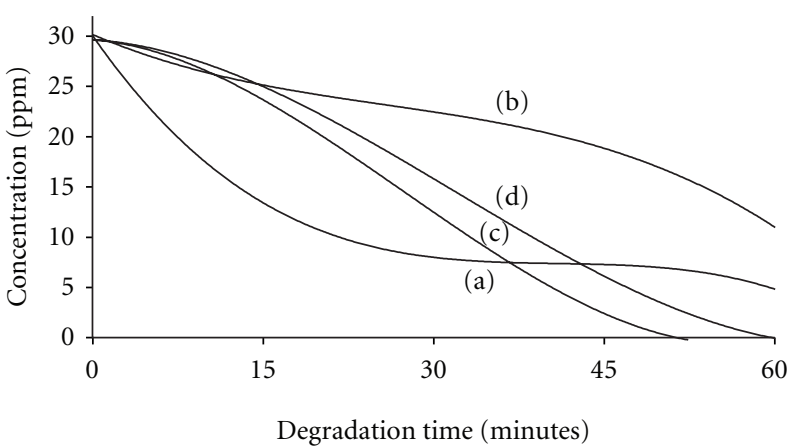

Figure 9: Photodegradation of $\mathrm{MO}$ on $\mathrm{TiO}_{2}-\mathrm{SiO}_{2}$ with various $\mathrm{Si}$ content, prepared at pH 3: (a) $0 \% \mathrm{Si}$, (b) $16 \% \mathrm{Si}$, (c) $25 \% \mathrm{Si}$, and (d) $50 \% \mathrm{Si}$.

the FTIR results of the sample ( $\mathrm{pH} 3)$ possessed high intensity of hydroxyl group. The result also indicates that samples prepared at basic conditions showed the poor MO degradation, which is in agreement with the observations of $\mathrm{Yu}$ et al. [23]. They revealed that amorphous $\mathrm{TiO}_{2}$ has a lower photocatalytic activity compared with crystalline $\mathrm{TiO}_{2}$. Hence, $\mathrm{SiO}_{2}$-loaded $\mathrm{TiO}_{2}$ powder prepared under basic conditions is inefficient for high photodegradation.

To understand the degradation of MO with time, samples were irradiated and collected every $15 \mathrm{~min}$. Pure $\mathrm{TiO}_{2}$ showed rapid degradation at the beginning, which eventually remained constant after $15 \mathrm{~min}$ (Figure 9). This is due to the low anatase concentration of $\mathrm{TiO}_{2}$ and its inherent structure and low surface area. The $\mathrm{TiO}_{2}$ with 25 and $50 \mathrm{~mol} \% \mathrm{SiO}_{2}$ had low degradation rate during the first $15 \mathrm{~min}$. Afterward, degradation markedly increased; both samples completely degraded $\mathrm{MO}$ within $1 \mathrm{~h}$. It is worth while to note that the complete mineralization of MO in sample SA25 was faster than that of sample SA50. The $\mathrm{TiO}_{2}$ with $25 \mathrm{~mol} \% \mathrm{SiO}_{2}$ exhibited the highest photocatalytic activity, which can be attributed to the combination of several factors including large surface area, high degree of anatase crystallinity, and improved surface acidity. Hence, an optimum amount of $\mathrm{SiO}_{2}(25 \mathrm{~mol} \%)$ added to $\mathrm{TiO}_{2}$ systems may be essential to enhance the photocatalytic activity.

Since SA25 was found to be the best sample for MO degradation, this was used to investigate the effect of $\mathrm{pH}$ on photocatalytic activity. The $\mathrm{TiO}_{2}-\mathrm{SiO}_{2}$ powder prepared at pH 3 and pH 5 showed the highest photocatalytic activity (Figure 10). Rapid degradation rates were observed and resulted in nearly $100 \%$ degradation of MO. In contrast, the photocatalytic activity of samples prepared at $\mathrm{pH} 7,9$, and 12 were very low. Samples from neutral conditions $(\mathrm{pH} 7)$ had the anatase structure and high crystallinity but showed lower photocatalytic activity. As the $\mathrm{pH}$ increased from 3 to 7 , the crystallite size increased, while the surface area decreased, which resulted in lower photocatalytic activity. These observations also indicate that a neutral environment for the synthesis could not enhance the photocatalytic activity. Overall, $\mathrm{TiO}_{2}$ powder loaded with $25 \mathrm{~mol} \% \mathrm{SiO}_{2}$ prepared at $\mathrm{pH} 3$ was the sample with the highest photocatalytic activity. 


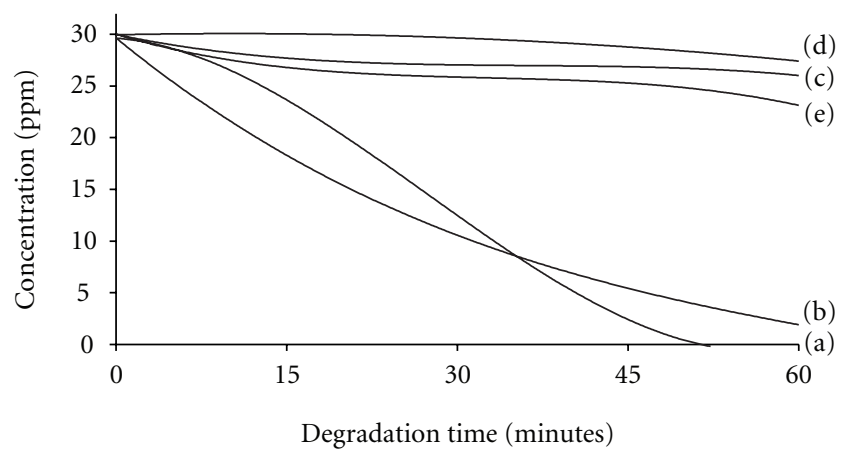

Figure 10: Photodegradation of $\mathrm{MO}$ on $\mathrm{TiO}_{2}-25 \mathrm{~mol} \% \mathrm{SiO}_{2}$ powder prepared at various $\mathrm{pH}$ values: (a) $\mathrm{pH} 3$, (b) $\mathrm{pH}$ 5, (c) $\mathrm{pH} 7$, (d) pH 9, and (e) pH 12.

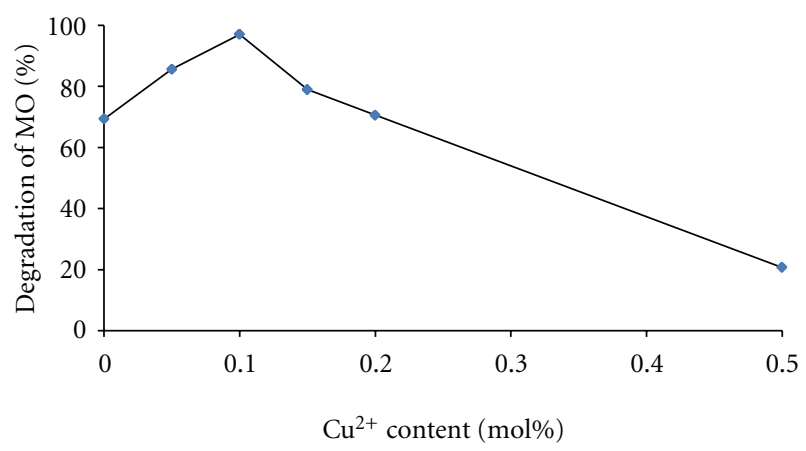

Figure 11: Photodegradation of $\mathrm{MO}(1 \mathrm{~h})$ on $\mathrm{Cu}^{2+}$-loaded $\mathrm{TiO}_{2}$ $25 \mathrm{~mol} \% \mathrm{SiO}_{2}$ powder prepared at $\mathrm{pH} 3$.

To investigate the effect of $\mathrm{Cu}^{2+}$ on photocatalytic activity, SA25 was loaded with varying amounts of $\mathrm{Cu}^{2+}$. The photocatalytic activity was markedly enhanced in the presence of $\mathrm{Cu}^{2+}$ (Figure 11). About $97 \%$ of MO was mineralized with the addition of $0.1 \mathrm{~mol} \%$ of $\mathrm{Cu}^{2+}$. This is mainly due to the high degree of crystallinity of the samples and the capability of $\mathrm{Cu}^{2+}$ to induce the formation of new states close to the conduction band, which leads to reduction of the band gap energy and an increase in the photodegradation efficiency. However, as the $\mathrm{Cu}^{2+}$ increased, the photocatalytic activity decreased rapidly. The photocatalytic activity dropped to $\sim 21 \%$ when the $\mathrm{Cu}^{2+}$ content reached $0.5 \mathrm{~mol} \%$. This may be attributed to the low crystallinity and the behavior of $\mathrm{Cu}^{2+}$ at high concentrations, wherein it becomes a recombination center for the photo-induced electrons and holes thereby inhibits photocatalysis [20]. Hence, an optimum amount of $\mathrm{Cu}^{2+}$ in $\mathrm{TiO}_{2}-\mathrm{SiO}_{2}$ is essential to improve its photodegradation efficiency.

\section{Conclusion}

The effect of $\mathrm{SiO}_{2}$ content and $\mathrm{pH}$ value on the $\mathrm{TiO}_{2}$ photocatalytic activity was investigated. The addition of $\mathrm{SiO}_{2}$ into the $\mathrm{TiO}_{2}$ strongly affected the degree of crystallinity of the composite. The phase structure was dependent on $\mathrm{pH}$ value in the presence of $\mathrm{SiO}_{2}$. An acidic environment led to anatase phase formation, and samples prepared in basic conditions exhibited the amorphous phase. Addition of $\mathrm{SiO}_{2}$ improved the surface area of $\mathrm{TiO}_{2}$ particles by enhancing the surface acidity; this led to high photocatalytic activity compared with pure $\mathrm{TiO}_{2}$. A higher degree of $\mathrm{MO}$ degradation was produced by $\mathrm{TiO}_{2}$ samples with $25 \mathrm{~mol} \%$ $\mathrm{SiO}_{2}$ prepared at $\mathrm{pH}$. The $\mathrm{TiO}_{2}$ loaded with $0.1 \mathrm{~mol} \% \mathrm{Cu}^{2+}$ and $25 \mathrm{~mol} \% \mathrm{SiO}_{2}$ exhibited photocatalytic activity higher than that without $\mathrm{Cu}^{2+}$. Therefore, the optimum amount of $\mathrm{SiO}_{2}$ and $\mathrm{Cu}^{2+}$ and the $\mathrm{pH}$ during preparation were essential to achieving high photocatalytic $\mathrm{TiO}_{2}$ activity.

\section{Acknowledgments}

The authors would like to thank the Universiti Sains Malaysia Fundamental Research Grant Scheme (Grant no. 6071195) and the USM Fellowship for their sponsorship.

\section{References}

[1] S. Kathirvale, M. N. Muhd Yunus, K. Sopian, and A. H. Samsuddin, "Energy potential from municipal solid waste in Malaysia," Renewable Energy, vol. 29, no. 4, pp. 559-567, 2003.

[2] L. A. Manaf, M. A. A. Samah, and N. I. M. Zukki, "Municipal solid waste management in Malaysia: practices and challenges," Waste Management, vol. 29, no. 11, pp. 2902-2906, 2009.

[3] J. L. Graham, C. B. Almquist, S. Kumar, and S. Sidhu, "An investigation of nanostructured vanadia/titania catalysts for the oxidation of monochlorobenzene," Catalysis Today, vol. 88, no. 1-2, pp. 73-82, 2003.

[4] Y. Ide, K. Kashiwabara, S. Okada, T. Mori, and M. Hara, "Catalytic decomposition of dioxin from MSW incinerator flue gas," Chemosphere, vol. 32, no. 1, pp. 189-198, 1996.

[5] R. Weber, T. Sakurai, and H. Hagenmaier, "Low temperature decomposition of PCDD/PCDF, chlorobenzenes and PAHs by $\mathrm{TiO}_{2}$-based $\mathrm{V}_{2} \mathrm{O}_{5}-\mathrm{WO}_{3}$ catalysts," Applied Catalysis B: Environmental, vol. 20, no. 4, pp. 249-256, 1999.

[6] W. Choi, S. J. Hong, Y. S. Chang, and Y. Cho, "Photocatalytic degradation of polychlorinated dibenzo-p-dioxins on $\mathrm{TiO}_{2}$ film under UV or solar light irradiation," Environmental Science and Technology, vol. 34, no. 22, pp. 4810-4815, 2000.

[7] A. L. Linsebigler, G. Lu, and J. T. Yates Jr., "Photocatalysis on $\mathrm{TiO}_{2}$ surfaces: principles, mechanisms, and selected results," Chemical Reviews, vol. 95, no. 3, pp. 735-758, 1995.

[8] K. Hashimoto, H. Irie, and A. Fujishima, " $\mathrm{TiO}_{2}$ photocatalysis: a historical overview and future prospects," Japanese Journal of Applied Physics, vol. 44, no. 12, pp. 8269-8285, 2005.

[9] X. Chen and S. S. Mao, "Titanium dioxide nanomaterials: synthesis, properties, modifications and applications," Chemical Reviews, vol. 107, no. 7, pp. 2891-2959, 2007.

[10] X. Chen, "Titanium dioxide nanomaterials and their energy applications," Chinese Journal of Catalysis, vol. 30, no. 8, pp. 839-851, 2009.

[11] M. Bellardita, M. Addamo, A. di Paola et al., "Photocatalytic activity of $\mathrm{TiO}_{2} / \mathrm{SiO}_{2}$ systems," Journal of Hazardous Materials, vol. 174, no. 1-3, pp. 707-713, 2010.

[12] J. Bennani, R. Dillert, T. M. Gesing, and D. Bahnemann, "Physical properties, stability, and photocatalytic activity of transparent $\mathrm{TiO}_{2} / \mathrm{SiO}_{2}$ films," Separation and Purification Technology, vol. 67, no. 2, pp. 173-179, 2009. 
[13] Y. Arai, K. Tanaka, and A. L. Khlaifat, "Photocatalysis of $\mathrm{SiO}_{2}$ loaded $\mathrm{TiO}_{2}$," Journal of Molecular Catalysis A, vol. 243, no. 1, pp. 85-88, 2006.

[14] R. A. Aziz and I. Sopyan, "Synthesis of $\mathrm{TiO}_{2}-\mathrm{SiO}_{2}$ powder and thin film photocatalysts by sol-gel method," Indian Journal of Chemistry, vol. 48, no. 7, pp. 951-957, 2009.

[15] R. N. Viswanath and S. Ramasamy, "Study of $\mathrm{TiO}_{2}$ nanocrystallites in $\mathrm{TiO}_{2}-\mathrm{SiO}_{2}$ composites," Colloids and Surfaces A, vol. 133, no. 1-2, pp. 49-56, 1998.

[16] K. Y. Jung and S. B. Park, "Photoactivity of $\mathrm{SiO}_{2} / \mathrm{TiO}_{2}$ and $\mathrm{ZrO}_{2} / \mathrm{TiO}_{2}$ mixed oxides prepared by sol-gel method," Materials Letters, vol. 58, no. 22-23, pp. 2897-2900, 2004.

[17] S. R. Kumar, C. Suresh, A. K. Vasudevan, N. R. Suja, P. Mukundan, and K. G. K. Warrier, "Phase transformation in sol-gel titania containing silica," Materials Letters, vol. 38, no. 3, pp. 161-166, 1999.

[18] R. F. Chen, C. X. Zhang, J. Deng, and G. Q. Song, "Preparation and photocatalytic activity of $\mathrm{Cu}^{2+}$-doped $\mathrm{TiO}_{2} / \mathrm{SiO}_{2}$," International Journal of Minerals, Metallurgy and Materials, vol. 16, no. 2, pp. 220-225, 2009.

[19] H. Chun, T. Yuchao, and T. Hongxiao, "Characterization and photocatalytic activity of transition-metal-supported surface bond-conjugated $\mathrm{TiO}_{2} / \mathrm{SiO}_{2}$," Catalysis Today, vol. 90, no. 3-4, pp. 325-330, 2004.

[20] D. Zhang, "Enhanced photocatalytic activity for titanium dioxide by co-modification with copper and iron," Transition Metal Chemistry, vol. 35, no. 8, pp. 933-938, 2010.

[21] C. H. Kwon, J. H. Kim, I. S. Jung, H. Shin, and K. H. Yoon, "Preparation and characterization of $\mathrm{TiO}_{2}-\mathrm{SiO}_{2}$ nanocomposite thin films," Ceramics International, vol. 29, no. 8, pp. 851-856, 2003.

[22] L. Zhou, S. Yan, B. Tian, J. Zhang, and M. Anpo, "Preparation of $\mathrm{TiO}_{2}-\mathrm{SiO}_{2}$ film with high photocatalytic activity on PET substrate," Materials Letters, vol. 60, no. 3, pp. 396-399, 2006.

[23] J. G. Yu, J. C. Yu, and X. Zhao, "The effect of $\mathrm{SiO}_{2}$ addition on the grain size and photocatalytic activity of $\mathrm{TiO}_{2}$ thin films," Journal of Sol-Gel Science and Technology, vol. 24, no. 2, pp. 95-103, 2002.

[24] G. Xu, Z. Zheng, Y. Wu, and N. Feng, "Effect of silica on the microstructure and photocatalytic properties of titania," Ceramics International, vol. 35, no. 1, pp. 1-5, 2009.

[25] P. Cheng, M. Zheng, Y. Jin, Q. Huang, and M. Gu, "Preparation and characterization of silica-doped titania photocatalyst through sol-gel method," Materials Letters, vol. 57, no. 20, pp. 2989-2994, 2003.

[26] Z. Li, B. Hou, Y. Xu et al., "Comparative study of sol-gelhydrothermal and sol-gel synthesis of titania-silica composite nanoparticles," Journal of Solid State Chemistry, vol. 178, no. 5, pp. 1395-1405, 2005.

[27] M. Hirano and K. Ota, "Direct formation and photocatalytic performance of anatase $\left(\mathrm{TiO}_{2}\right)$ /silica $\left(\mathrm{SiO}_{2}\right)$ composite nanoparticles," Journal of the American Ceramic Society, vol. 87, no. 8, pp. 1567-1570, 2004.

[28] J. G. Yu, Y. Su, B. Cheng, and M. Zhou, "Effects of pH on the microstructures and photocatalytic activity of mesoporous nanocrystalline titania powders prepared via hydrothermal method," Journal of Molecular Catalysis A, vol. 258, no. 1-2, pp. 104-112, 2006.

[29] A. Karami, "Synthesis of $\mathrm{TiO}_{2}$ nano powder by the sol-gel method and its use as a photocatalyst," Journal of the Iranian Chemical Society, vol. 7, no. 1, pp. S154-S160, 2010.
[30] K. Guan, B. Lu, and Y. Yin, "Enhanced effect and mechanism of $\mathrm{SiO}_{2}$ addition in super-hydrophilic property of $\mathrm{TiO}_{2}$ films," Surface and Coatings Technology, vol. 173, no. 2-3, pp. 219223, 2003.

[31] J. G. Yu, H. Yu, B. Cheng, and C. Trapalis, "Effects of calcination temperature on the microstructures and photocatalytic activity of titanate nanotubes," Journal of Molecular Catalysis A, vol. 249, no. 1-2, pp. 135-142, 2006.

[32] J. G. Yu, H. Yu, B. Cheng, X. Zhao, and Q. Zhang, "Preparation and photocatalytic activity of mesoporous anatase $\mathrm{TiO}_{2}$ nanofibers by a hydrothermal method," Journal of Photochemistry and Photobiology A, vol. 182, no. 2, pp. 121-127, 2006.

[33] Y. Q. Wang, G. Q. Hu, X. F. Duan, H. L. Sun, and Q. K. Xue, "Microstructure and formation mechanism of titanium dioxide nanotubes," Chemical Physics Letters, vol. 365, no. 5-6, pp. 427-431, 2002.

[34] K. Guan, "Relationship between photocatalytic activity, hydrophilicity and self-cleaning effect of $\mathrm{TiO}_{2} / \mathrm{SiO}_{2}$ films," Surface and Coatings Technology, vol. 191, no. 2-3, pp. 155-160, 2005. 

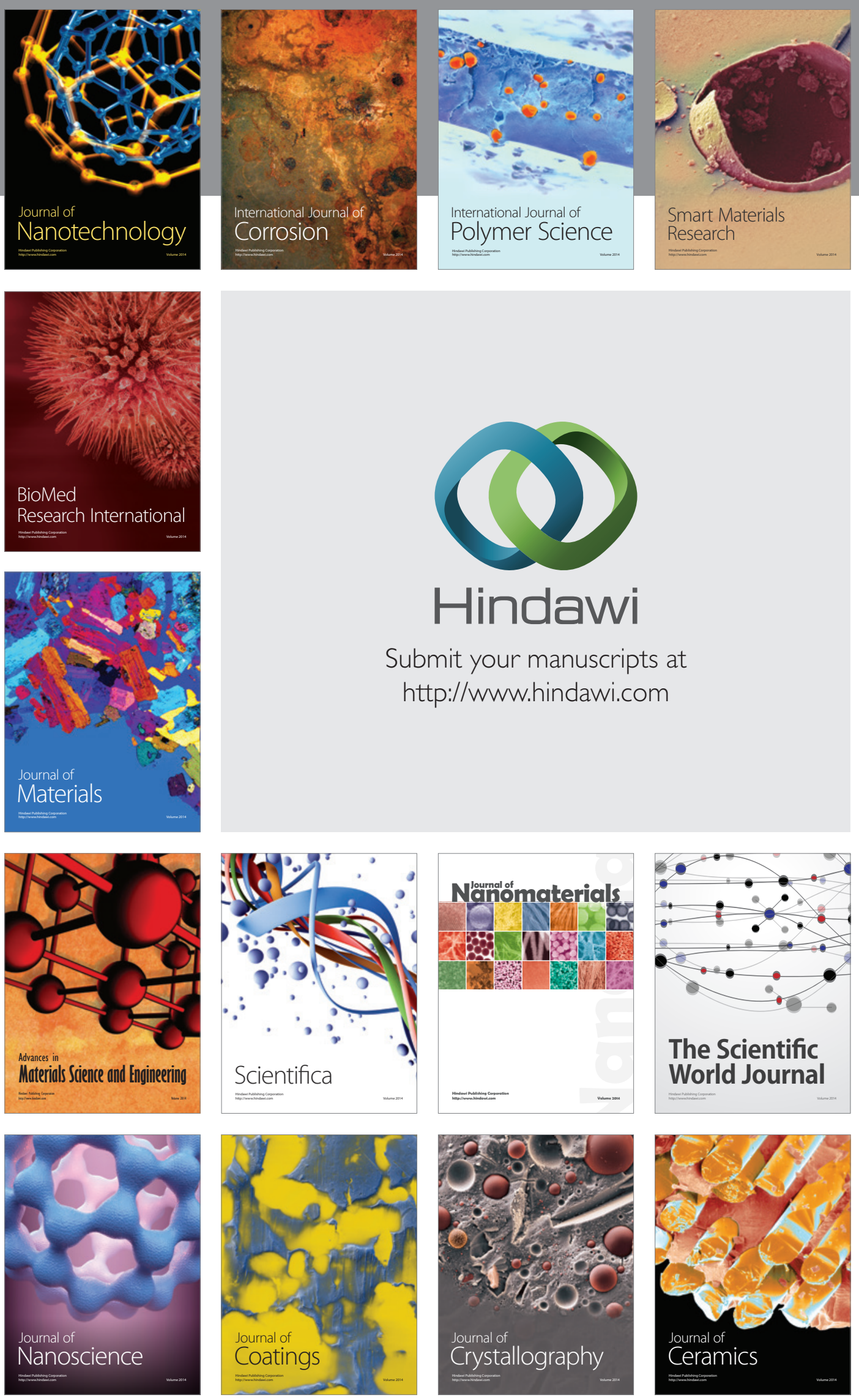

The Scientific World Journal

Submit your manuscripts at

http://www.hindawi.com

\section{World Journal}

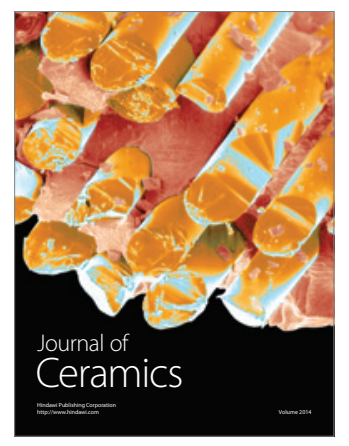

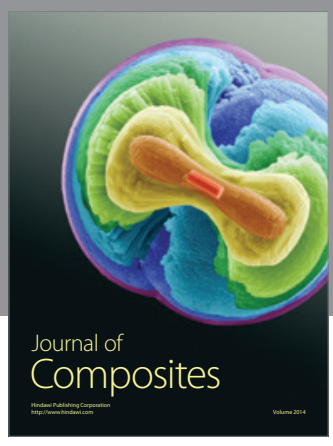
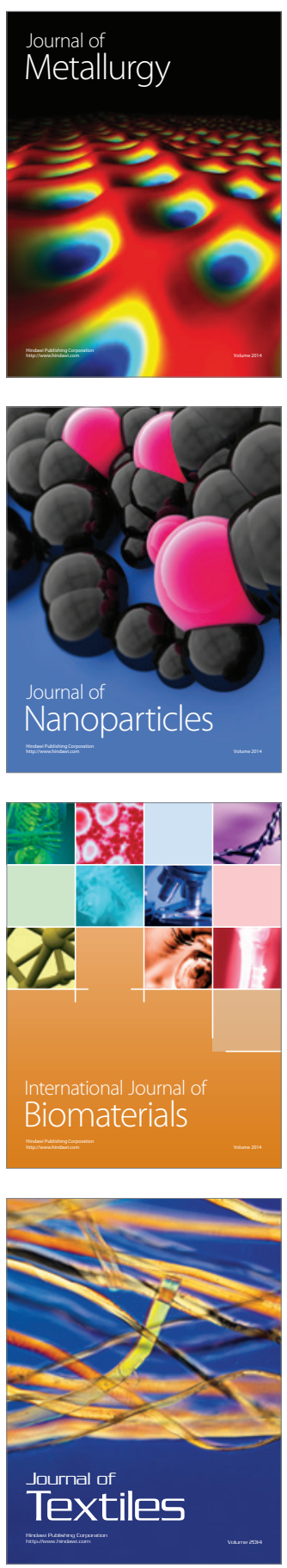